Open Access

\title{
Reflections on the innovative city: examining three innovative locations in a knowledge bases framework
}

\author{
Tommi Inkinen
}

\author{
Correspondence: tommi.inkinen@ \\ helsinki.fi \\ Department of Geosciences and \\ Geography, University of Helsinki, \\ Helsinki 00014, Finland
}

\begin{abstract}
This paper combines three location-based cases with literature background focusing on knowledge bases and cities. The paper considers the regional context of the city of Helsinki and its surrounding area (HMA). Analyzed cases include three specific locations highlighting urban form, connectivity and knowledge-intensive production. Conceptually innovative cities are experiencing extensive change as they transform and change in order to become competitive providers of first class living for highly skilled global work-force. The integration of spatial characteristics into analyses of knowledge intensiveness of cities brings forth new theoretical openings for urban analysis setting platforms for open innovation and economy. The paper focuses on extensive material resources collected in numerous projects. The data gives more reliable picture of the knowledge-intensive locations compared to single interviews or survey studies. The total data includes work and education statistics, stakeholder interviews and observation field work. Provided reflections are classified according to key issues presented in urban studies and economic geography.
\end{abstract}

\section{Springer}

\section{Background}

An innovation is a new product or service, material or immaterial, with a market demand that separates it from an invention. Innovation is one of the most widely used concepts in the current literature of economic geography highlighting the importance of regions in innovative development. Regions themselves are targets of numerous policies enhancing a complex interaction between processes of education, the labor market, and the economy. Cities, on the other hand, are regional nodes. They may be studied as economic agglomerations, and are deemed as motors of economic development that result in the accumulation of wellbeing and wealth. Simmie (2005) provided a critical overview of the spatial innovation literature focusing on economic agglomerations. Accordingly concepts such as industrial districts, clusters, innovative milieu, regional innovation systems and learning regions provide a conceptual point of departure when considering innovation. These concepts are operationalized in regional and urban analysis through locationbased terminology such as science parks, knowledge hubs, knowledge precincts, technology parks, or living labs (e.g., Anttiroiko 2004). This paper will focus on three cases from the Helsinki Metropolitan Area (HMA) in Finland. The cases represent novel examples of urban innovative locations.

(c) 2015 Inkinen. Open Access This article is distributed under the terms of the Creative Commons Attribution 4.0 International License (http://creativecommons.org/licenses/by/4.0/), which permits unrestricted use, distribution, and reproduction in any medium, provided you give appropriate credit to the original author(s) and the source, provide a link to the Creative Commons license, and indicate if changes were made. 
The change and renovation of urban form has been variously depicted as one of the key challenges in growing cities. Technology has been deemed as one of the enablers of change and open innovation based economic development (Chesbrough 2003; Chesbrough et al. 2014). Particularly, increasing environmental pressures cause a growing need to develop new and cleaner solutions for open innovation in transport and industry. Economic growth merges together with continuous growth of cities in terms of their population and critical mass. Background factors are also identified in initializing innovative economic growth. The most important one is education and its related learning capability: Tertiary education is the most constant explanatory variable in the analysis of innovative regions and cities (Makkonen \& Inkinen 2013). The importance of education and the existence of university units precede the emergence of innovative small and medium-sized enterprises (SMEs) and start-up companies that are commonly recognized as significant indicators of an active and flourishing open innovation environment.

This paper approaches the innovative city as follows. First, I will reflect on selected theories and typologies used in the analysis of innovative cities. Second, I will address the presented theories in accordance with qualitative interpretations founded on various projects conducted during the years between 2010 and 2014 (Appendix 1). The collected data concerns Finnish cities and locations, particularly in the Helsinki Metropolitan Area (HMA) including the most important cities of Helsinki, Espoo and Vantaa that are studied and motivated with statistics. Third, the paper considers theoretical propositions in the light of the knowledge bases framework and provides a reflective discussion on the current condition of the innovative city.

\section{Innovation systems and knowledge bases}

There are two main concepts widely used in current studies on economic geography and innovative cities: innovation system and knowledge base. Related key-concepts include tacit and explicit, translation and transfer, change and transformation that are associated with complex innovation environments. The locational advantage in economic production stems from aggregating organizational production as measurable indicators. All these are intertwined together. On micro-scale innovations, created in organizations and their collaborative or joint networks, sum-up as an aggregate location-based (development) indicator. Innovations may be calculated through direct innovations counts, patents (given and applied) or in some cases research and development inputs (expenditure and employment). The translation from micro-level to aggregate macro-level causes both attraction effect (in-bound agglomeration) and spill-over effect (out-bound dispersing). It also induces a cost increase and labor demand for highly educated people. Lundvall \& Maskell (2000, 359-361) explain the traditions behind the concept of "innovation systems" in their account of national production and business systems. They indicate that the innovation system approach was conceived in the 1980s mainly in the works of Freeman (1987) and Lundvall (1985) in order to explain regional and urban development. The theoretical foundation is built on the understanding that economic activity agglomerates and there are clear and identifiable processes behind it. The concept was finally established as the collaboration between Freeman (e.g., 1990), Lundvall (1992) and Nelson (1993). Komninos (2002) notes that 
the innovation system theory is influenced by evolutionary economics traceable back to the Schumpeterian tradition.

The underlying tradition of contemporary debate indicates the intersection between economic geography and economics. Where economists commonly highlight the importance of measurable variables concerning organizations (or more narrowly profit making firms), economic geographers tend to highlight the specifics and locational contexts that are embedded into the societal and cultural fabric of that particular location. Geels and Schot (2007) have provided a typology incorporating time with local structuration. They apply a layered triad divided into following the main components: Socio-technical landscape (exogenous context); socio-technical regime; and niche-innovations. Radical innovations are fundamental for niches as they function through small-scale networks and flexible environments. The emergence of a radical innovation (in a spatial location) and its transition towards larger spatial scales of markets is intertwined with socio-technical regime in which it is embedded. However, incremental innovations differ to a large extent from the radical ones as they are usually products of long term experience and progressive enhancements.

Asheim et al. $(2011,898)$ divide innovation knowledge into analytical, synthetic and symbolic bases. The three dimensions refer broadly to a fluid transition from hard codified and transferable knowledge towards creative and imaginative aspects of innovations (Table 1). These function as the platform for an empirical case study (see Tables 2 and 3). Similar approaches might for example be called quantifiable knowledge, applicable knowledge, and artistic (or creative) knowledge. The distinction of different knowledge bases is a starting point in the definition of an innovative city. Most often knowledge-intensive (or innovative) locales include universities or their affiliates (in one form or another), businesses that are knowledge-intensive thus requiring skills and knowledge that universities provide, and sophisticated governance

Table 1 Knowledge bases framework (modified from Asheim \& Gertler 2005; Asheim et al. 2011)

\begin{tabular}{|c|c|c|c|}
\hline $\begin{array}{l}\text { Description } \\
\text { and indicator }\end{array}$ & $\begin{array}{l}\text { Analytical (focusing on } \\
\text { science base) }\end{array}$ & $\begin{array}{l}\text { Synthetic (focusing on } \\
\text { engineering and applied } \\
\text { sciences) }\end{array}$ & $\begin{array}{l}\text { Symbolic (focusing on arts and } \\
\text { creativity) }\end{array}$ \\
\hline $\begin{array}{l}\text { Reason for } \\
\text { knowledge } \\
\text { production }\end{array}$ & $\begin{array}{l}\text { Developing new } \\
\text { knowledge by scientific } \\
\text { principles (causality and to } \\
\text { know "why" }\end{array}$ & $\begin{array}{l}\text { Appling and combining existing } \\
\text { knowledge into a new product } \\
\text { or service (integration and to } \\
\text { know "how"?) }\end{array}$ & $\begin{array}{l}\text { Producing and creating } \\
\text { meaning and significance: } \\
\text { desire, aesthetic, symbols and } \\
\text { meanings (giving meaning and } \\
\text { to know "who"? }\end{array}$ \\
\hline $\begin{array}{l}\text { Use of } \\
\text { knowledge } \\
\text { and } \\
\text { development } \\
\text { of ideas }\end{array}$ & $\begin{array}{l}\text { Deductive; Causality; } \\
\text { modelling }\end{array}$ & $\begin{array}{l}\text { Problem solving and targeted } \\
\text { production (custom); induction }\end{array}$ & Creativity and uniqueness \\
\hline $\begin{array}{l}\text { Actors } \\
\text { involved }\end{array}$ & $\begin{array}{l}\text { Internal and external } \\
\text { collaboration between } \\
\text { research units }\end{array}$ & $\begin{array}{l}\text { Interaction between customers } \\
\text { and producers. Involves } \\
\text { learning processes. }\end{array}$ & $\begin{array}{l}\text { Experimentation and artistic } \\
\text { and creative work }\end{array}$ \\
\hline $\begin{array}{l}\text { Knowledge } \\
\text { types }\end{array}$ & $\begin{array}{l}\text { Codified knowledge, } \\
\text { universality, abstract }\end{array}$ & $\begin{array}{l}\text { Partially codified, strong tacit } \\
\text { element, recognizes context }\end{array}$ & $\begin{array}{l}\text { Strong context and case } \\
\text { specificity, interpretation, } \\
\text { cultural knowledge }\end{array}$ \\
\hline $\begin{array}{l}\text { Importance } \\
\text { of spatiality }\end{array}$ & $\begin{array}{l}\text { Meaning is location free } \\
\text { and small variation }\end{array}$ & $\begin{array}{l}\text { Meaning varies between } \\
\text { locations and location specifics } \\
\text { have an importance }\end{array}$ & $\begin{array}{l}\text { Meaning varies between } \\
\text { observers and socio-economic } \\
\text { conditions }\end{array}$ \\
\hline $\begin{array}{l}\text { Examples } \\
\text { of outcomes }\end{array}$ & $\begin{array}{l}\text { Biochemistry products, } \\
\text { medicine development }\end{array}$ & $\begin{array}{l}\text { Product engineering, interface } \\
\text { design, manufacturing }\end{array}$ & $\begin{array}{l}\text { Cultural products, branding and } \\
\text { images }\end{array}$ \\
\hline
\end{tabular}


Table 2 Knowledge bases framework in relation to selected variables

\begin{tabular}{llll}
\hline Code & Content & Primary knowledge base & Secondary knowledge base \\
\hline $\mathrm{K}$ & Information and communication & Synthetic & Analytical \\
71 & Finance and insurance & Synthetic & Analytical \\
72 & Scientific research and development & Analytical & Analytical \\
73 & Advertising and marketing research & Synthetic & Synthetic \\
74 & Specialized business services & Synthetic & Symbolic \\
854 & Tertiary (highest) education & Analytical & Symbolic \\
R & Arts, entertainment, recreation & Symbolic & Synthetic \\
\hline
\end{tabular}

integrating national and municipal (or regional) legislations and administrative processes. Etzkowitz and Klofsten (2005) have developed this idea based on the triple-helix concept: Regional advantage and development occurs through a triad of interaction and collaborative arrangement between the public sector (administration and governance), businesses (motors of innovation creation) and universities (educators and enablers of academic knowledge).

Table 1 classification is a background for statistics selection (see Tables 2 and 3) for establishing the time trends for case locations. These statistics give grounds to argue the varying importance of knowledge base profiles for each unique case location and they highlight the spatial characteristics of an innovation (e.g. Crevoisier 2004). They define the employment profiles for innovative surroundings boosting new ideas in order to promote both local and national economy.

The innovative city as knowledge platforms

The concept of an "innovative city" may be used as a marketing slogan for urban environments in order to build-up their reputation and image. This is particularly important in Helsinki and the HMA as Finland's remote location does not automatically attract a high level of foreign investments. Therefore the marketing demand becomes pronounced in the attraction process. In terms of used marketing strategies, Helsinki has experienced an extensive shift since the 1950s (see Jokela 2014). For more than a decade, cities have experienced the need to be identified as "innovative." The need seems to apply also to other, often science-based, concepts that are regarded as creators of a positive contemporary image. Technological development and progress are goals that are easily accepted as universal goals to which all cities should aim. Therefore, innovative cities may be considered through societal context and global economic pressure.

Second, the innovative city may be considered through the overall technological profile that the city provides through public organizations and the private sector. For example, the wide availability of free Wi-Fi networks gives an indication of a knowledge-accessible location and highly developed service provision (Inkinen 2010). The technological profile is connectable to the broader thematic of well-functioning urban form. The technological aspect embeds into the environment as the resource of information in varying material spaces. In other words, urban parks, urban plazas, services, infrastructures provide the setting for information infrastructures and wireless applications. The existence of a broad 
Table 3 Statistical indicators of knowledge intensive work places in study areas. Cities of Helsinki and Espoo are added as references for three case locations. Source: Statistics Finland 2015

\begin{tabular}{|c|c|c|c|c|c|c|c|}
\hline $\begin{array}{l}\text { Area code } \\
\text { and location }\end{array}$ & SIC code and content & 2008 & 2009 & 2010 & 2011 & $\begin{array}{l}\text { Absolute growth } \\
\text { 2008-2011 }\end{array}$ & $\begin{array}{l}\% \text { of total } \\
\text { Workplaces } \\
\text { (2011) }\end{array}$ \\
\hline \multirow[t]{9}{*}{091 Helsinki } & $\begin{array}{l}J \text { Information and } \\
\text { communication }\end{array}$ & 36063 & 35585 & 35262 & 35980 & -83 & $9,3 \%$ \\
\hline & K Finance and insurance & 18328 & 18677 & 18914 & 19172 & 844 & $5,0 \%$ \\
\hline & $\begin{array}{l}71 \text { Architecture and } \\
\text { engineering services }\end{array}$ & 9619 & 8208 & 8504 & 8879 & -740 & $2,3 \%$ \\
\hline & $\begin{array}{l}72 \text { Scienctific research } \\
\text { and development }\end{array}$ & 5516 & 5278 & 5284 & 4839 & -677 & $1,3 \%$ \\
\hline & $\begin{array}{l}73 \text { Advertising and } \\
\text { marketing research }\end{array}$ & 5328 & 4946 & 5302 & 5355 & 27 & $1,4 \%$ \\
\hline & $\begin{array}{l}74 \text { Specialiced business } \\
\text { services }\end{array}$ & 3473 & 3444 & 3591 & 3770 & 297 & $1,0 \%$ \\
\hline & $\begin{array}{l}854 \text { Tertirary (highest) } \\
\text { education }\end{array}$ & 9273 & 9727 & 10525 & 10492 & 1219 & $2,7 \%$ \\
\hline & $\begin{array}{l}\text { R Arts, entertainment, } \\
\text { recreation }\end{array}$ & 9885 & 10260 & 10175 & 10322 & 437 & $2,7 \%$ \\
\hline & TOTAL & 97485 & 96125 & 97557 & 98809 & 1324 & $25,6 \%$ \\
\hline \multirow[t]{9}{*}{$\begin{array}{l}091201 \\
\text { Ruoholahti }\end{array}$} & $\begin{array}{l}J \text { Information and } \\
\text { communication }\end{array}$ & 2007 & 2124 & 1916 & 3093 & 1086 & $19,5 \%$ \\
\hline & K Finance and insurance & 382 & 1709 & 1698 & 1767 & 1385 & $11,2 \%$ \\
\hline & $\begin{array}{l}71 \text { Architecture and } \\
\text { engineering services }\end{array}$ & 157 & 191 & 151 & 203 & 46 & $1,3 \%$ \\
\hline & $\begin{array}{l}72 \text { Scienctific research } \\
\text { and development }\end{array}$ & 7 & 6 & 59 & 127 & 120 & $0,8 \%$ \\
\hline & $\begin{array}{l}73 \text { Advertising and } \\
\text { marketing research }\end{array}$ & 209 & 186 & 144 & 118 & -91 & $0,7 \%$ \\
\hline & $\begin{array}{l}74 \text { Specialiced business } \\
\text { services }\end{array}$ & 88 & 86 & 90 & 107 & 19 & $0,7 \%$ \\
\hline & $\begin{array}{l}854 \text { Tertirary (highest) } \\
\text { education }\end{array}$ & 47 & 50 & 49 & 65 & 18 & $0,4 \%$ \\
\hline & $\begin{array}{l}\text { R Arts, entertainment, } \\
\text { recreation }\end{array}$ & 203 & 217 & 250 & 271 & 68 & $1,7 \%$ \\
\hline & TOTAL & 3100 & 4569 & 4357 & 5751 & 2651 & $36,3 \%$ \\
\hline \multirow[t]{9}{*}{$\begin{array}{l}091232 \\
\text { Arabianranta }\end{array}$} & $\begin{array}{l}J \text { Information and } \\
\text { communication }\end{array}$ & 215 & 234 & 98 & 104 & -111 & $3,5 \%$ \\
\hline & K Finance and insurance & 28 & 25 & 22 & 22 & -6 & $0,7 \%$ \\
\hline & $\begin{array}{l}71 \text { Architecture and } \\
\text { engineering services }\end{array}$ & 374 & 22 & 24 & 34 & -340 & $1,1 \%$ \\
\hline & $\begin{array}{l}72 \text { Scienctific research } \\
\text { and development }\end{array}$ & 0 & 0 & 0 & 0 & 0 & $0,0 \%$ \\
\hline & $\begin{array}{l}73 \text { Advertising and } \\
\text { marketing research }\end{array}$ & 91 & 25 & 65 & 64 & -27 & $2,1 \%$ \\
\hline & $\begin{array}{l}74 \text { Specialiced business } \\
\text { services }\end{array}$ & 28 & 30 & 36 & 36 & 8 & $1,2 \%$ \\
\hline & $\begin{array}{l}854 \text { Tertirary (highest) } \\
\text { education }\end{array}$ & 687 & 662 & 669 & 764 & 77 & $25,4 \%$ \\
\hline & $\begin{array}{l}\text { R Arts, entertainment, } \\
\text { recreation }\end{array}$ & 81 & 94 & 94 & 80 & -1 & $2,7 \%$ \\
\hline & TOTAL & 1504 & 1092 & 1008 & 1104 & -400 & $36,6 \%$ \\
\hline 049 Espoo & $\begin{array}{l}J \text { Information and } \\
\text { communication }\end{array}$ & 9424 & 9020 & 9735 & 10693 & 1269 & $8,8 \%$ \\
\hline
\end{tabular}


Table 3 Statistical indicators of knowledge intensive work places in study areas. Cities of Helsinki and Espoo are added as references for three case locations. Source: Statistics Finland 2015 (Continued)

\begin{tabular}{|c|c|c|c|c|c|c|c|}
\hline & K Finance and insurance & 4326 & 4083 & 4006 & 3978 & -348 & $3,3 \%$ \\
\hline & $\begin{array}{l}71 \text { Architecture and } \\
\text { engineering services }\end{array}$ & 4505 & 4454 & 4363 & 4433 & -72 & $3,7 \%$ \\
\hline & $\begin{array}{l}72 \text { Scienctific research } \\
\text { and development }\end{array}$ & 2756 & 2708 & 2524 & 3047 & 291 & $2,5 \%$ \\
\hline & $\begin{array}{l}73 \text { Advertising and } \\
\text { marketing research }\end{array}$ & 905 & 1160 & 1018 & 978 & 73 & $0,8 \%$ \\
\hline & $\begin{array}{l}74 \text { Specialiced business } \\
\text { services }\end{array}$ & 760 & 739 & 799 & 735 & -25 & $0,6 \%$ \\
\hline & $\begin{array}{l}854 \text { Tertirary (highest) } \\
\text { education }\end{array}$ & 3816 & 4101 & 4356 & 4542 & 726 & $3,8 \%$ \\
\hline & $\begin{array}{l}\text { R Arts, entertainment, } \\
\text { recreation }\end{array}$ & 2167 & 2319 & 2472 & 2714 & 547 & $2,2 \%$ \\
\hline & TOTAL & 28659 & 28584 & 29273 & 31120 & 2461 & $25,7 \%$ \\
\hline $\begin{array}{l}049222 \\
\text { Otaniemi }\end{array}$ & $\begin{array}{l}J \text { Information and } \\
\text { communication }\end{array}$ & 2441 & 2346 & 2878 & 3327 & 886 & $16,8 \%$ \\
\hline & K Finance and insurance & 63 & 85 & 100 & 80 & 17 & $0,4 \%$ \\
\hline & $\begin{array}{l}71 \text { Architecture and } \\
\text { engineering services }\end{array}$ & 1157 & 1321 & 1234 & 812 & -345 & $4,1 \%$ \\
\hline & $\begin{array}{l}72 \text { Scienctific research } \\
\text { and development }\end{array}$ & 2438 & 2465 & 2284 & 2307 & -131 & $11,6 \%$ \\
\hline & $\begin{array}{l}73 \text { Advertising and } \\
\text { marketing research }\end{array}$ & 92 & 316 & 259 & 262 & 170 & $1,3 \%$ \\
\hline & $\begin{array}{l}74 \text { Specialiced business } \\
\text { services }\end{array}$ & 43 & 68 & 93 & 61 & 18 & $0,3 \%$ \\
\hline & $\begin{array}{l}854 \text { Tertirary (highest) } \\
\text { education }\end{array}$ & 3347 & 3631 & 3505 & 4070 & 723 & $20,5 \%$ \\
\hline & $\begin{array}{l}R \text { Arts, entertainment, } \\
\text { recreation }\end{array}$ & 63 & 74 & 59 & 88 & 25 & $0,4 \%$ \\
\hline & TOTAL & 9644 & 10306 & 10412 & 11007 & 1363 & $55,5 \%$ \\
\hline
\end{tabular}

service platform contributes to the quality of life when considered through availability of services and a clean environment. Focusing on the individual, an innovative city, therefore has to be a location with the potential to offer desirable living conditions for highly skilled and educated professionals. These factors include, for example, a well-functioning education system, health services, a clean and safe environment, and various alternatives for consumption, including goods and services together with cultural and social events (Yigitcanlar \& Löngvist Yigitcanlar and Lönnqvist 2013).

Third, the innovative city may be projected through specific areas and locations within the city. Extensive varieties exist in terms of how science parks, university campuses, business districts and cultural milieus visually present themselves. Sometimes they are strictly bordered locations that distinctively differ from their surroundings and sometimes they fuse into the urban fabric in an organic manner. Functionality of administration and city (or local) government and governance is an important factor in the development of cities and planning. There are several principles depicting good administrative processes. They include the transparency of decision making and the electoral system of city representatives; transparent and optimized public service provision; and the division between in-house service production and outsourcing. 
Public-Private-Partnerships have proved to be an efficient solution in developing new innovative services for local inhabitants and visitors.

Earlier case studies (e.g., Simmie 2001) have demonstrated that each innovative city has its own historical trajectory and contextual specifics that have driven each one on its path towards successful, high-skilled production. Path dependency and evolutionary economic theory have a significant role in the understanding of contemporary cities and their economic and social innovations (Martin \& Sunley 2006; 2007). However, critical assessments have also been presented (Simmie 2005). The main issues concern the complex process of production innovations in distributed networks. Innovative collaboration thus does not need to be fixed in a single location even though the individuals comprising the network always have a specific context.

The innovative city is actualized and characterized by knowledge-intensive locals within the urban fabric. Based on these considerations the concept of an innovative city may be defined as an urban location that actively promotes and highlights the role of knowledge-intensiveness and technological advancement as one of the defining characteristics associated with the city. The innovative city is often referred to as a smart city; this refers to the use of communication and sensor technologies in urban context. Intelligent systems - i.e., communicating and information sharing technologies and architectures - lie at the heart of the concept. However, on the level of the whole urban structure, the innovative city should be considered as a meta-concept reflecting the "feeling" or the "spirit" of that particular location.

\section{Bridging innovation bases and the innovative city}

Cities provide the actual context for innovative growth. The knowledge bases approach, discussed above, highlights the significance of a university education as the motivator and engine of analytical and synthetic knowledge. The practical implications include how to transfer university-based learning to applications. Commonly this interface is realized through start-up companies and incubators. Since Lundvall's (1992) proposition of national innovation systems the concept of "innovation" is deemed as both resource and tool to promote the knowledge-economy. Numerous studies have brought together elements that are collectively involved in the location-based development. PPPs, triple-helix and knowledge bases are recognized contributors required to establish an innovative city.

The distinction between knowledge-intensiveness, innovation, and creativity needs to be addressed. According to Table 1, a majority of work-tasks related to the analytical (scientific) knowledge base are dependent on codified knowledge and are commonly transferable from one individual to another. The description is well geared to analytical sciences such as biotechnology, medicine and natural sciences but less well to social sciences or humanities. The question boils down to reasoning about the author (or innovator) as an individual in the scientific process. If a single researcher has significance in the process, then the codified aspect loses some of its explanatory power. Fields of science that apply qualitative approaches as their main tools to assess human activities are commonly more biased toward the symbolic knowledge base than the scientific one. The role of the interpreter, and signification, becomes an element of the innovative process. The knowledge base typology as an instrumental part of innovation systems requires more detailed contributions concerning the role and essence of different disciplines of science. 
A key-consideration is the distinction between analytical and synthetic knowledge bases. Engineering also emphasizes codified knowledge, but according to variations presented (Asheim \& Gertler 2005; Asheim et al. 2007; Gertler 2008; Asheim et al. 2011), the synthetic knowledge base is also deemed to rely strongly on tacit knowledge. The Knowledge base approach has been critically assessed by Manniche (2012), who points out the generic essence of the triad and therefore the recognition that several industries draw their innovativeness from different knowledge bases and the distinction between them should be viewed as a spectrum and not as strictly separate categories.

A broad definition of knowledge commonly recognizes two forms of knowledge: tacit and codified. Between the two forms there exists a process of transfer. Nonaka and Takeuchi's (1995) theoretical approach became a popular application of knowledge transfer and the interplay of tacit and codified knowledge taking place within an organization. The knowledge transfer involving socialization and externalization together with internalization and the combination within an organization requires common understanding, trust, and most importantly a common goal. These function as an impetus for interchanging tacit knowledge into codified and explicit knowledge.

Knowledge intensiveness, urban development, and innovation are tightly interlinked: urban measures for assessing a city's innovation level or creativeness are often based on measures involving university education or self-obtained high-level skills such as programming, visual or analytical design (utilization of graphic design software) and other capabilities based on talent. Spatial scaling, taking place in the knowledge transfer process, is an understudied dimension in the knowledge transfer analysis. Incremental innovations particularly emerge in complex project networks that are often spatially distributed on the global scale. The creation of an innovative business environment must therefore include individuals as the fundamental resource. The knowledge transfer between individuals, teams, and networks plays a key-role in the emergence of (successful) innovation.

\section{Selected urban cases}

The studied case locations are from Finland and more particularly from the HMA. The context of Helsinki, as a knowledge city, has been studied in our earlier works (Inkinen \& Vaattovaara 2007; 2010; Makkonen and Inkinen 2014; Yigitcanlar et al. 2015). Briefly, Helsinki together with its surrounding cities of Espoo and Vantaa comprise a modern Northern European capital area that functions as the economic engine for the whole country. As a national capital Helsinki also hosts the most important public sector organizations, including parliament and ministries of the national government.

Municipal division is an interesting one in the context of Helsinki and Finland. Helsinki metropolitan area is not an official regional category: it is used to identify a total of 12 municipalities under one concept depicting a geographical area surrounding Helsinki. The question of municipal borders is highly relevant as the main cities (Helsinki, Espoo, and Vantaa) clearly comprise a functional area but administrative local government borders break the area into three separate legal entities with their 
own city councils, planning, and taxation. This is a textbook example of how naturally functioning areas should not be divided by administrative (political) borders.

The selected three cases represent a variety of characteristics defining the concept of an innovative city. Figure 1 shows the geography of each study location within the HMA. The geographical proximity is interesting here as both Arabianranta and Keilaniemi-Otaniemi have a similar 5-kilometer distance to the Center of Helsinki. An administrative border exists also as Keilaniemi-Otaniemi is part of the city of Espoo.

The satellite images in Fig. 1 show three intensively built-up locations with their distinct characteristics. The first area (left) is Arabianranta with its clear-cut dual profile: the built-up residential area and the factory building in the middle; and Toukola shore-park (rantapuisto) green area. The Center of Helsinki (middle) is a typical urban center with small green areas scattered around blocks of buildings. The center is also characterized by the main railway station terminal occupying a large proportion of the land area in the Center of Helsinki. Keilaniemi-Otaniemi (right) is an example of a location stretching along the main transport route. The buildings are clustered on the east side of the area. Otaniemi, hosting the Aalto University's main campus, is located above the Keilaniemi business district.

I approach the innovative city from the socio-technical viewpoint and use a typology approach in classifying elements from three case areas from the Helsinki metropolitan area. Selected statistics are presented in Tables 3 and 4 and analysis in Tables 5 and 6. Knowledge base classification with characterizations of each selected cases is presented in Table 2: the cases are Arabianranta residential area (entitled as a "living lab"); 2) the cultural and economic core is presented by Ruoholahti that is one of the innovative hotspots in the center of Helsinki; and 3) Keilaniemi and Otaniemi (technological cluster and host headquarters for several major companies). The classification includes the following elements:

- knowledge base characteristic

- spatial characteristics (buildings and green areas)

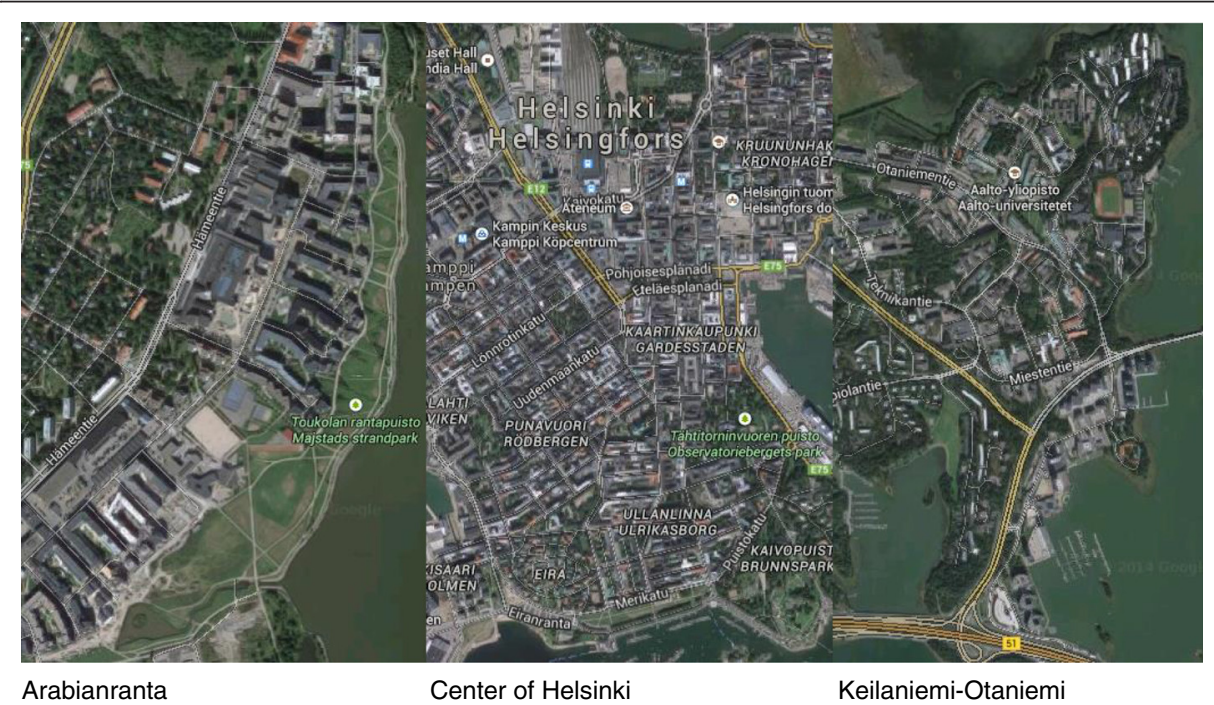

Arabianranta

Center of Helsinki

Keilaniemi-Otaniemi

Fig. 1 Satellite view of the study locations in the HMA. Source: Google Earth 
Table 4 Persons with Masters, Licentiate and Doctoral degrees living in study locations with growth indicators

\begin{tabular}{|c|c|c|c|c|c|c|c|c|c|c|c|}
\hline Location and gender & $\begin{array}{l}\text { Total population } 2014 \\
\text { (16 till } 64 \text { years) }\end{array}$ & 2008 & 2009 & 2010 & 2011 & 2012 & 2013 & 2014 & Per pop. (2014) & $\begin{array}{l}\text { Growth } \\
2008-2014\end{array}$ & $\begin{array}{l}\text { Growth \% } \\
\text { 2008-2014 }\end{array}$ \\
\hline 091 Helsinki & 429682 & 70611 & 73535 & 78787 & 80734 & 83684 & 86559 & 90009 & $20,9 \%$ & 19398 & $27,5 \%$ \\
\hline Men & 207937 & 34338 & 35506 & 37472 & 38238 & 39586 & 40670 & 41922 & $20,2 \%$ & 7584 & $22,1 \%$ \\
\hline Women & 221745 & 36273 & 38029 & 41315 & 42496 & 44098 & 45889 & 48087 & $21,7 \%$ & 11814 & $32,6 \%$ \\
\hline 091 Ruoholahti & 2238 & 359 & 355 & 358 & 353 & 372 & 355 & 366 & $16,4 \%$ & 7 & $1,9 \%$ \\
\hline Men & 1095 & 169 & 166 & 172 & 170 & 178 & 171 & 174 & $15,9 \%$ & 5 & $3,0 \%$ \\
\hline Women & 1143 & 190 & 189 & 186 & 183 & 194 & 184 & 192 & $16,8 \%$ & 2 & $1,1 \%$ \\
\hline 091 Arabianranta & 4620 & 462 & 568 & 741 & 836 & 925 & 1072 & 1172 & $25,4 \%$ & 710 & $153,7 \%$ \\
\hline Men & 2162 & 209 & 254 & 330 & 368 & 410 & 468 & 513 & $23,7 \%$ & 304 & $145,5 \%$ \\
\hline Women & 2458 & 253 & 314 & 411 & 468 & 515 & 604 & 659 & $26,8 \%$ & 406 & $160,5 \%$ \\
\hline 049 Espoo & 172815 & 34363 & 35733 & 37349 & 38527 & 40107 & 41195 & 42432 & $24,6 \%$ & 8069 & $23,5 \%$ \\
\hline Men & 86799 & 18573 & 19135 & 19701 & 20225 & 21113 & 21515 & 22073 & $25,4 \%$ & 3500 & $18,8 \%$ \\
\hline Women & 86016 & 15790 & 16598 & 17648 & 18302 & 18994 & 19680 & 20359 & $23,7 \%$ & 4569 & $28,9 \%$ \\
\hline 049 Otaniemi & 3533 & 211 & 234 & 239 & 253 & 302 & 331 & 362 & $10,2 \%$ & 151 & $71,6 \%$ \\
\hline Men & 2455 & 138 & 149 & 157 & 170 & 205 & 226 & 254 & $10,3 \%$ & 116 & $84,1 \%$ \\
\hline Women & 1078 & 73 & 85 & 82 & 83 & 97 & 105 & 108 & $10,0 \%$ & 35 & $47,9 \%$ \\
\hline
\end{tabular}


Table 5 ANOVA comparison test results for group differences

\begin{tabular}{|c|c|c|c|c|c|c|}
\hline & & Sum of Squares & $d f$ & Mean Square & $\mathrm{F}$ & Sig. \\
\hline \multirow[t]{3}{*}{ InfoCom } & Between locations & 3482119136,00 & 4 & 870529784,000 & 3781,140 &, 000 \\
\hline & Within locations & 3453441,750 & 15 & 230229,450 & & \\
\hline & Total & 3485572577,75 & 19 & & & \\
\hline \multirow[t]{3}{*}{ Finance } & Between locations & 1009622403,50 & 4 & 252405600,875 & 2083,778 &, 000 \\
\hline & Within locations & 1816932,250 & 15 & 121128,817 & & \\
\hline & Total & 1011439335,75 & 19 & & & \\
\hline \multirow[t]{3}{*}{ ArchEng } & Between locations & 222075604,000 & 4 & 55518901,000 & 609,162 &, 000 \\
\hline & Within locations & 1367097,750 & 15 & 91139,850 & & \\
\hline & Total & 223442701,750 & 19 & & & \\
\hline \multirow[t]{3}{*}{ SciRes } & Between locations & 75651636,500 & 4 & 18912909,125 & 682,886 &, 000 \\
\hline & Within locations & 415433,250 & 15 & 27695,550 & & \\
\hline & Total & 76067069,750 & 19 & & & \\
\hline \multirow[t]{3}{*}{ AdverMan } & Between locations & 78014632,800 & 4 & 19503658,200 & 1615,685 &, 000 \\
\hline & Within locations & 181071,750 & 15 & 12071,450 & & \\
\hline & Total & 78195704,550 & 19 & & & \\
\hline \multirow[t]{3}{*}{ SpecBus } & Between locations & 36982388,300 & 4 & 9245597,075 & 1983,573 &, 000 \\
\hline & Within locations & 69916,250 & 15 & 4661,083 & & \\
\hline & Total & 37052304,550 & 19 & & & \\
\hline \multirow[t]{3}{*}{ TertEdu } & Between locations & 249315247,800 & 4 & 62328811,950 & 545,146 &, 000 \\
\hline & Within locations & 1715012,000 & 15 & 114334,133 & & \\
\hline & Total & 251030259,800 & 19 & & & \\
\hline \multirow[t]{3}{*}{ Arts } & Between locations & 301983694,300 & 4 & 75495923,575 & 4059,146 &, 000 \\
\hline & Within locations & 278984,500 & 15 & 18598,967 & & \\
\hline & Total & 302262678,800 & 19 & & & \\
\hline
\end{tabular}

- organizational characteristics (derived from planning)

- relative location and accessibility (modes of transport and travel time)

- university presence

- municipality (2 in Helsinki, 1 in Espoo)

- institutional diversity and knowledge bases

- characteristics of economic actors

Knowledge base characteristic refers to the classification of Table 1 (see Asheim et al. 2011), in order to demonstrate the observable variations in the specifics of the cases. Spatial characteristics refers to building designs (height, materials, design) and the use of green areas and other visual elements specific to the location. Organizational characteristics are derived from regional and local planning, giving backbone to spatial characteristics. Thus the two categories are interlinked. Relative accessibility is essential for all locations - thus how accessible they are in terms of travel time and number of connections. This is a question of infrastructure bandwidth.

The university presence is perhaps the most topical in defining an innovative city (for education statistics see Table 4). There might also be a drawback here as universities teach research (methodology) that is bound by its own set of rules and practices defining the essence of scientific inquiry. Innovative activities and creativity might 
Table 6 Concise results of Tamhane's T2 multiple comparisons

\begin{tabular}{|c|c|c|c|c|c|c|}
\hline \multirow{2}{*}{$\begin{array}{l}\text { Tamhane's T2 results } \\
\text { Field of industry }\end{array}$} & \multicolumn{2}{|l|}{ Ruoholahti } & \multicolumn{2}{|l|}{ Arabianranta } & \multicolumn{2}{|l|}{ Otaniemi } \\
\hline & $\begin{array}{l}\text { Sig. difference } \\
\text { to ( } 95 \% \\
\text { significance) }\end{array}$ & $\begin{array}{l}\text { Non } \\
\text { significant } \\
\text { difference }\end{array}$ & $\begin{array}{l}\text { Sig. difference } \\
\text { to ( } 95 \% \\
\text { significance) }\end{array}$ & $\begin{array}{l}\text { Non } \\
\text { significant } \\
\text { difference }\end{array}$ & $\begin{array}{l}\text { Sig. } \\
\text { difference to } \\
\text { (95\% significance) } \\
\end{array}$ & $\begin{array}{l}\text { Non } \\
\text { significant } \\
\text { difference }\end{array}$ \\
\hline $\begin{array}{l}\text { Information and } \\
\text { communication }\end{array}$ & $\begin{array}{l}\text { Helsinki } \\
\text { Arabianranta } \\
\text { Espoo }\end{array}$ & Otaniemi & $\begin{array}{l}\text { Helsinki } \\
\text { Ruoholahti } \\
\text { Espoo } \\
\text { Otaniemi }\end{array}$ & & $\begin{array}{l}\text { Helsinki } \\
\text { Arabianranta } \\
\text { Espoo }\end{array}$ & Ruoholahti \\
\hline $\begin{array}{l}\text { Finance and } \\
\text { insurance }\end{array}$ & $\begin{array}{l}\text { Helsinki } \\
\text { Espoo }\end{array}$ & $\begin{array}{l}\text { Arabianranta } \\
\text { Otaniemi }\end{array}$ & $\begin{array}{l}\text { Helsinki } \\
\text { Espoo } \\
\text { Otaniemi }\end{array}$ & Ruoholahti & $\begin{array}{l}\text { Helsinki } \\
\text { Arabianranta } \\
\text { Espoo }\end{array}$ & Ruoholahti \\
\hline $\begin{array}{l}\text { Architecture and } \\
\text { engineering }\end{array}$ & $\begin{array}{l}\text { Helsinki } \\
\text { Espoo } \\
\text { Otaniemi }\end{array}$ & Arabianranta & $\begin{array}{l}\text { Helsinki } \\
\text { Espoo } \\
\text { Otaniemi }\end{array}$ & Ruoholahti & $\begin{array}{l}\text { Helsinki } \\
\text { Ruoholahti } \\
\text { Arabianranta } \\
\text { Espoo }\end{array}$ & \\
\hline Scientific R\&D & $\begin{array}{l}\text { Helsinki Espoo } \\
\text { Otaniemi }\end{array}$ & Arabianranta & $\begin{array}{l}\text { Helsinki } \\
\text { Espoo } \\
\text { Otaniemi }\end{array}$ & Ruoholahti & $\begin{array}{l}\text { Helsinki } \\
\text { Ruoholahti } \\
\text { Arabianranta }\end{array}$ & Espoo \\
\hline $\begin{array}{l}\text { Advert. and } \\
\text { marketing research }\end{array}$ & $\begin{array}{l}\text { Helsinki } \\
\text { Arabianranta } \\
\text { Espoo }\end{array}$ & Otaniemi & $\begin{array}{l}\text { Helsinki } \\
\text { Espoo }\end{array}$ & $\begin{array}{l}\text { Ruoholahti } \\
\text { Otaniemi }\end{array}$ & $\begin{array}{l}\text { Helsinki } \\
\text { Espoo }\end{array}$ & $\begin{array}{l}\text { Ruoholahti } \\
\text { Arabianranta }\end{array}$ \\
\hline $\begin{array}{l}\text { Specialized business } \\
\text { services }\end{array}$ & $\begin{array}{l}\text { Helsinki } \\
\text { Arabianranta } \\
\text { Espoo }\end{array}$ & Otaniemi & $\begin{array}{l}\text { Helsinki } \\
\text { Ruoholahti } \\
\text { Espoo }\end{array}$ & Otaniemi & $\begin{array}{l}\text { Helsinki } \\
\text { Espoo }\end{array}$ & Ruoholahti \\
\hline $\begin{array}{l}\text { Tertiary (highest) } \\
\text { education }\end{array}$ & $\begin{array}{l}\text { Helsinki } \\
\text { Arabianranta } \\
\text { Espoo } \\
\text { Otaniemi }\end{array}$ & & $\begin{array}{l}\text { Helsinki } \\
\text { Arabianranta } \\
\text { Espoo } \\
\text { Otaniemi }\end{array}$ & & $\begin{array}{l}\text { Helsinki } \\
\text { Ruoholahti } \\
\text { Arabianranta }\end{array}$ & Espoo \\
\hline $\begin{array}{l}\text { Arts, entertainment, } \\
\text { recreation }\end{array}$ & $\begin{array}{l}\text { Helsinki } \\
\text { Arabianranta } \\
\text { Espoo } \\
\text { Otaniemi }\end{array}$ & & $\begin{array}{l}\text { Helsinki } \\
\text { Ruoholahti } \\
\text { Espoo }\end{array}$ & Otaniemi & $\begin{array}{l}\text { Helsinki } \\
\text { Ruoholahti } \\
\text { Espoo }\end{array}$ & Arabianranta \\
\hline
\end{tabular}

also occur by other sets of rules than the scientific approach taken into account in the knowledge segments (particularly the symbolic base and the arts). The selected cases are justifiable as they present a variety of locational characteristics identified in the literature concerning innovative locales. They also present different forms in the urban fabric: Arabianranta is a residential area, whereas the Keilaniemi-Otaniemi area is a typical business district. The Center of Helsinki, on the other hand, is a traditional European capital center that hosts government facilities for all spatial layers of administration starting from the city organizations and ending with the international affiliations that Finland possess.

"Institutional diversities and knowledge bases" is theoretically the most interesting segment as the category includes core elements raised in the literature: business-public sector division and the sphere observable from the study cases. The distinction is made concerning three main observation units: universities, public sector offices, and profit-making companies. Characteristics of economic actors instead refer to company diversity - what knowledge intensive industries they present and how extensive their impact is in terms of employment and turnover (Inkinen \& Kaakinen 2015).

\section{Statistical evidence}

In order to present a motivated and statistically grounded view of the study locations the Tables 2 and 3 are presented. They indicate the workplace profile both in the 
cities of Helsinki and Espoo and their specific study areas. SIC2008 statistics concern work places in selected fields of knowledge intensive occupations. First, the employment figures for education are interesting as all the locations have a significant number of employees in the field. This is also expected as study locations host at least one university in their vicinity. The central tendency of spatial clustering towards urban cores shows in the figures of finance. The Center of Helsinki is the dominant finance cluster in Finland and the sector is strongly agglomerated and embedded into it. The other two cases have less than 100 persons in finance. These small figures also indicate the reduction in the number of local bank offices and the current trend in banking business that stresses large customer interface units commonly located in the urban center.

Table 2 motivation for knowledge bases framework is identified as follows: Majority of research and knowledge driven economy relies on synthetic knowledge as it is the base for engineering and applied solutions including social profession such as finance and legal services. Analytical base is also strongly present through scientific and research and education professions (professors and university teachers). Symbolic base is dominant in the fields of arts. The selection criteria for these statistical classes is founded on earlier research using similar data resources (e.g. Musterd et al. 2007; Yigitcanlar et. al. Yigitcanlar et al. 2015). These classes are operationalized in Table 3 indicating key measures of work places in knowledge locations.

Another key feature in regional innovation studies has been recognition of education as the main force behind the locational human capital and resulting academic labor market and innovation system (e.g. Rutten \& Boekema 2013). Table 4 indicates the extensive growth observable in the study locations concerning the highest level education. The selected degrees include only the Masters, Licentiate and PhD degree holders and their relative proportion of the local population.

Education statistics in Table 4 show that selected cases differ extensively according to their educated population. Arabianranta has experienced significant growth that can be explained by the construction and expansion of new apartment buildings to the area during 2008 till 2014. Ruoholahti instead has been readily build already in 2008 and the changes of education profile have been small. Overall both the cities of Helsinki and Espoo have gained a healthy 20-25 \% growth. Table 4 also indicates that female had educated themselves more than males with continuous trend since 2008. This has been a typical characteristic in Finnish society for the past 20 years.

Statistical observation indicates that all study areas exceed their reference (cities of Helsinki and Espoo) counterparts in terms of amount of knowledge bases variables. In order to ensure the differentiated profiles of each location a statistical analysis was conducted by using Analysis of Variances (ANOVA) that produces a variance measure for a quantitative dependent variable by a single factor (independent) variable. Analysis of variance is used to test the hypothesis that several means are equal. This technique is an extension of the two-sample t-test. ANOVA is robust to departures from normality, although the data should be symmetric. The analyzed groups come from populations with unequal variances according to Levene's homogeneity. Therefore nonparametric post hoc Tamhane's T2 test was applied in order to produce more detailed understanding of group differences. Tamhane T2 test is a pairwise multiple 
comparisons test indicating the difference between each pair of means and yield a matrix indicating significantly different group means at significance level of 0.05 . Tamhane's T2 is a conservative pairwise comparisons test and it is based on a t-test. It is appropriate when the variances are unequal as is the case in this data.

Tamhane's T2 results are presented on the concise form in Table 6 (full analysis in Appendix 2; Table 8). According to the statistical analysis all employment fields differ from each other significantly. Tamhane's test revealed that Arabianranta and Otaniemi have the most distinct work profiles according to knowledge bases classification. Tamhene's comparison indicates that study areas are the most similar to each other in the fields of Architecture and engineering as well as professions in tertiary education. The analysis also shows that the greatest variations exists in the fields of finance and insurance together with advertising and marketing research. The general interpretation from both Tables 5 and 6 is that selected industries have significant differences and therefore motivate the study locations to be studied further in a qualitative manner.

\section{Reflections and discussion}

Tables 3 and 4 presents the most important background statistics in order to shed light on the innovative characteristics of these locations. These include industrial profile (SIC2008) and the number and growth of highly educated people living in study areas. Geographically (physical distances) the three study locations are relatively similar in their sizes. In terms of employment levels the areas differ greatly: the center area has three times as many employees than Keilaniemi-Otaniemi and 20 times more than Arabianranta. In the case of Helsinki the liveliness and attractiveness of the urban center is evident. The decaying effect of the central business districts experienced in some US cities is not observable in Helsinki. Considering the numbers of residents and households in the Center of Helsinki, the city may be argued to provide a relatively healthy platform for urban development including the core center.

Keilaniemi-Otaniemi foci on information and communication professions and manufacturing are clearly present in the relative importance of the sectors of Table 6 . An interesting notion concerns the number of employed persons working in arts, entertainment, and recreational services: It is very modest in both the Arabianranta area and the Keilaniemi-Otaniemi area, whereas the presence is stronger in the Center of Helsinki. This is an important finding as Arabianranta organizes, provides and installs art events and creativity-based outdoor happenings to promote the location and its image. Table 7 presents the classified spatial characteristics in order to summarize the observed distinctiveness of each study location. It includes selected key-aspects describing and explaining innovative urban locations.

Table 7 indicates the main differences among the study locations. The knowledge base characteristic is the most defining one. To begin with, Arabianranta is entitled a "living lab" by a local residential development company (www.helsinkilivinglab.fi) aiming to enhance local conditions both for living standards and business. The activities denoting this are carried out in various projects ranging from art exhibitions to participatory social media and technology development. Bringing all these aspects together, an alternative way of looking at an innovative city is found in Arabianranta. 
Table 7 Summary of the studied innovative city locations in the knowledge bases framework

\begin{tabular}{|c|c|c|c|}
\hline & Arabianranta & Keilaniemi-Otaniemi & Center of Helsinki \\
\hline $\begin{array}{l}\text { Knowledge base } \\
\text { characteristic }\end{array}$ & $\begin{array}{l}\text { Symbolic - art and design } \\
\text { dominated residential } \\
\text { district }\end{array}$ & $\begin{array}{l}\text { Synthetic - engineering and } \\
\text { ICT production hub }\end{array}$ & $\begin{array}{l}\text { Analytical combining } \\
\text { synthetic and symbolic }\end{array}$ \\
\hline $\begin{array}{l}\text { Spatial } \\
\text { characteristics } \\
\text { (buildings and } \\
\text { green areas) }\end{array}$ & $\begin{array}{l}\text { Low building profile (max } \\
10 \text { floors); extensive green } \\
\text { areas (managed), water- } \\
\text { front }\end{array}$ & $\begin{array}{l}\text { High building profile (max } 25 \\
\text { floors); limited green areas } \\
\text { mainly in natural condition; } \\
\text { water-front }\end{array}$ & $\begin{array}{l}\text { Low building profile (max } 10 \\
\text { floors); very limited green } \\
\text { areas (city parks); CBD and } \\
\text { old design }\end{array}$ \\
\hline $\begin{array}{l}\text { Organizational } \\
\text { characteristics } \\
\text { (derived from } \\
\text { planning) }\end{array}$ & $\begin{array}{l}\text { Residential area; limited } \\
\text { number of businesses; } \\
\text { strong focus on residential } \\
\text { buildings }\end{array}$ & $\begin{array}{l}\text { Business district; business } \\
\text { design; applications of steel, } \\
\text { concrete and glass }\end{array}$ & $\begin{array}{l}\text { Old town planning derivable } \\
\text { to } 19 \text { th century; combination } \\
\text { of business structures and } \\
\text { residential buildings }\end{array}$ \\
\hline $\begin{array}{l}\text { Relative location } \\
\text { and accessibility } \\
\text { (modes of } \\
\text { transport and } \\
\text { travel time) }\end{array}$ & $\begin{array}{l}\text { Peripheral. Central distance } \\
7 \text { km via roads; limited car } \\
\text { parking and access; } \\
\text { efficient public transport }\end{array}$ & $\begin{array}{l}\text { Mediocre. Central distance } \\
7 \mathrm{~km} \text { via roads; efficient car } \\
\text { access and parking; mediocre } \\
\text { public transport }\end{array}$ & $\begin{array}{l}\text { Central node. Highly efficient } \\
\text { public transport (intermodal, } \\
\text { all modes); limited car } \\
\text { parking and access }\end{array}$ \\
\hline University presence & $\begin{array}{l}\text { Aalto University: School of } \\
\text { Art, Design and } \\
\text { Architecture }\end{array}$ & $\begin{array}{l}\text { Aalto University: Helsinki } \\
\text { University of Technology } \\
\text { (main campus) }\end{array}$ & $\begin{array}{l}\text { University of Helsinki; Aalto } \\
\text { University: School of } \\
\text { Business; Sibelius Academy }\end{array}$ \\
\hline $\begin{array}{l}\text { Municipality ( } 2 \text { in } \\
\text { Helsinki, } 1 \text { in } \\
\text { Espoo) }\end{array}$ & Helsinki & Espoo & Helsinki \\
\hline $\begin{array}{l}\text { Institutional } \\
\text { diversity and } \\
\text { knowledge bases }\end{array}$ & $\begin{array}{l}\text { Strong focus on art and } \\
\text { design; combination of } \\
\text { symbolic knowledge } \\
\text { resources; living lab }\end{array}$ & $\begin{array}{l}\text { High technology ICT } \\
\text { engineering; Combination of } \\
\text { synthetic and analytical } \\
\text { knowledge bases and } \\
\text { software production }\end{array}$ & $\begin{array}{l}\text { Multitude of actors and } \\
\text { activities; Fragmented } \\
\text { structures and combination } \\
\text { of all knowledge bases }\end{array}$ \\
\hline $\begin{array}{l}\text { Characteristics of } \\
\text { economic actors }\end{array}$ & $\begin{array}{l}\text { Art and design retailing; } \\
\text { Small production; Services; } \\
\text { Restaurants }\end{array}$ & $\begin{array}{l}\text { Corporate headquarters: ICT; } \\
\text { Oil refining; Industrial } \\
\text { engineering }\end{array}$ & $\begin{array}{l}\text { Multitude of functions: } \\
\text { Headquarters; Finance and } \\
\text { services; Legal services; PR } \\
\text { and consulting }\end{array}$ \\
\hline
\end{tabular}

The area is a textbook example of a creative milieu with a strong symbolic knowledge base. Architecturally and commercially the Arabianranta is strongly influenced by the old factory building of Arabia, a company that originally manufactured porcelain plates and pottery. Today the factory building is supplemented with large additional structures hosting a number of design producers and their retailing facilities. The new expanded structure is currently called "Arabia Center." The residential area is developed and planned around the old factory buildings indicating the connection between creativity and urban planning.

Arabianranta hosts the old University of Art and Design that is currently one of the three schools within the Aalto University. This design university locates in a factory building of Arabia explicating the strong symbolic knowledge base. In terms of desirable living conditions, the number and quality of green areas are the most extensive and sophisticated in Arabianranta among the three cases. From the Arabianranta's total land area approximately $30 \%$ is green. These include park type of managed green areas as well as shore areas. Arabianranta is also connected to an extensive central park in Helsinki that provides an undisturbed channel of forest and park areas from the Center of Helsinki to surrounding rural areas. The residential area has hosted a number of art shows and outdoor exhibitions on the main plaza close to the Arabia Center. For example in 2014 there were a total of 103 happenings and art or urban-culture associated events (arabianranta.fi). 
Keilaniemi-Otaniemi is located in the city of Espoo, an integral part of the capital area. The location is a textbook example of an industrial district relying on a strong synthetic knowledge base. The area hosts several headquarters of major Finnish companies such as the petroleum company Neste. The engineering emphasis that defines the spirit of the whole area derives also from the very close proximity (less than one kilometer) of Aalto University's main campus (the old Helsinki University of Technology). This location represents an elaborate case of business-university intertwinement. The location is also one of the driving motors of the Finnish economy. The area has grown steadily both in terms of employers (companies) and number of employees. An indication of this is the continuous construction and renovation of the area regardless of the contemporary economic stagnation.

The Center of Helsinki is the third and final example of the reflections on the innovative city. The center area itself is mainly business driven but it also hosts more than 20,000 households. The housing prices are among the highest in Finland in this area. As the focal point of the city, the center area provides an ensemble of various services, organizations, and structures defining an urban form. The center area combines the essence of each of the knowledge bases and particularly the scientific one. This is realized two ways: first the center area of a capital city embeds the history and administrative tradition. The history is explicit in the formation of the Finnish nation and in the structure of its organization. Second, the main administration and a number of faculties of the University of Helsinki are located in the center area. The scientific knowledge base is not understood here only as an explicit codified science but also as the existence and significance of the university institution itself for the city. This is also implicated in the name change of one of the most central metro stations: The old Kaisaniemi station was renamed the University of Helsinki station at the beginning of 2015.

As indicated, the innovative city concept requires a number of actualized elements characteristic of the knowledge-driven and future-oriented location. These elements include a clean and safe environment, walkability, environmentally friendly solutions in urban planning, the use of innovative urban design and a combination of different purposes for different locations such as parks or public buildings such as libraries. All the visible structures (the built environment) embed invisible technologies: the availability and existence of networks and communication systems, the sophistication of real-time urban management, the response capability in the event of disruptions and accidents, and the availability of location-based information (Crevoisier 2014).

Reflecting on the characteristics of open innovation and economy each case location, the following interpretations may be drawn. First, each location depicts unique characteristics specific for each of these locals. These characteristics are identified in the statistics and may be approach through literature in order to illustrate the delicate balance between planned and organic formation of knowledge base locations. The cases might be considered as typical textbook examples providing their own location-specific elements in the fabric of an innovative city.

Second, the cases demonstrate functional differences and characteristics embodied in their spatiality. Each case study represents its own distinct spirit and feelings derived from the historic trajectories defining the character of the local. Arabianranta is characterized by a design- and art-driven ethos and the constructed closeness to green areas provide elements definable as a desirable living area, whereas Keilaniemi-Otaniemi project the image of a modern business environment through steel and glass architecture 
commonly preferred in headquarter designs. The Center area, on the other hand, culminates in a relatively new Northern European core center, hosting both businesses and residential blocks. The center area is also the commercial hotspot and the most common visiting site for tourists visiting Helsinki and the HMA.

Third, the mixture of industrial profiles (Table 3) is a straightforward indicator to consider locational specialization in the HMA space. The three cases have their distinct profiles in terms of their respective industries and services. Size matters as Arabianranta is hosting only small- and medium-sized companies employing less than 250 persons, whereas Keilaniemi-Otaniemi has significant international employers. The center area hosts a diverse business mix, in which a number of small businesses are located within close proximity to larger ones.

The observed case locations provide an insight into potential synergies that occur between companies and local actors in order to promote open innovative economy. Local resources such as the highly skilled labor base, organizational quality in public administration (transparency, efficiency, and service quality), and availability of financial resources are also highly relevant for well-functioning knowledge transfer. These resources in their specific locations act as the enablers of co-operation integrating innovation producers, customers, and suppliers as the stakeholders of the innovative production (Fagerberg \& Verspagen 2009). Capello (1999) studied this dimension in knowledge transfer from the point view of collective learning. The thematic is highly influential considering innovative small locations as platforms and enablers of these processes establishing an interesting future study direction: does the location influence the innovation learning patterns and knowledge transfer experienced by the companies located in the same area; and do company profile, size, and industrial field have an impact on this?

\section{Conclusions}

The applied statistics and qualitative typology revealed that the knowledge base approach functions well as an identification tool and analysis framework for the three cases of HMA. They present novel, open, innovative and knowledge-intensive urban locations indicating universal characteristics common to all open innovative environments. The main interpretations include that, first, different locations even in one national and regional context have their distinct traditions and pathways of development. The case of Keilaniemi-Otaniemi will be an interesting location for further observation as there are explicit plans to convert some of the office towers into residential apartment buildings. The clear-cut distinction between industrial and residential areas is diminishing as these areas are becoming mixed. The knowledge-intensive immaterial production (e.g., design, programming, management, and marketing) has a key part in the current development. Second, the studied locations have their distinct requirements for knowledge bases. Arabianranta is clearly attuned towards a symbolic and artistic base, whereas KeilaniemiOtaniemi is the clearest example of a synthetic base. The Center of Helsinki combines aspects from all three but it is strongly influenced by the presence of numerous universities. For example the multitudes of buildings and locations associated with the University of Helsinki, Aalto University's School of Business, and Sibelius Academy have a distinct and significant impact on the visual cityscape of Helsinki. Third, the studied cases elaborated the following interpretations on an innovative city: first, the cityscape's architectural and organizational structure has a defining role in considering the innovative-city concept. 
This intertwines the triple-helix concept with the knowledge base approach as universities and profit-making companies, together with numerous mediating organizations providing support services, comprise the backbone for a (potentially) innovative location.

There are multiple questions that may be addressed in future research. First, the spatial locations and accessibility of knowledge-intensive locations (or spots) within urban space requires further mapping and spatial analysis. The combination of organically embedded locations suitable for knowledge-intensive work and production could be contrasted with specifically designed (planned) areas that aim to create and establish something definable as knowledge-intensive local. Additional research needs are founded on this reasoning: How extensive are these locations and how numerous are they in relation to explanatory variables such as population, education, income, and economy? Finally, the analyses of evolutionary paths and history-based contexts for existing economic activity and potential future development are needed. Industries tend to change in time and technological development causes major evolutions in economic structures. Identification of major game changers and motivators of transition serves as both a challenge and a stimulus for future research.

\section{Appendix 1. List of projects providing the reflected data collected 2009-2014.}

Academy of Finland: Geography and Innovative Competitiveness? Finnish Knowledge Regions in European and Global Economy, 2009-2012: Quantitative statistics and GIS data; qualitative data including more than 20 expert interviews and field observations throughout the HMA.

Forest-industries: Wind power provision potentials in Finnish Regions, 2013: Qualitative report data concerning green development plans nationally and in several regions including Helsinki region (Uusimaa).

Helsinki Metropolitan Region Urban Research Program: Business perspective on innovative urban growth, 2014. Quantitative statistics and GIS data; qualitative data including 11 expert interviews and field observations in Helsinki, Espoo and Vantaa.

Helsinki Metropolitan Region Urban Research Program: Business perspective on innovative urban growth - Part II, 2015-2016. Qualitative data including more than 10 field observation tasks varying in duration from one week to two months.

\section{Appendix 2}

Table 8 Tamhane's T2 comparisons for study locations including reference cities of Helsinki and Espoo

\begin{tabular}{|c|c|c|c|c|c|c|c|}
\hline \multicolumn{8}{|c|}{ Multiple Comparisons } \\
\hline \multicolumn{8}{|l|}{ Tamhane } \\
\hline \multirow[t]{2}{*}{ Dependent } & \multirow{2}{*}{$\begin{array}{l}\text { (I) } \\
\text { LocCode }\end{array}$} & \multirow{2}{*}{$\begin{array}{l}\text { (J) } \\
\text { LocCode }\end{array}$} & \multirow{2}{*}{$\begin{array}{l}\text { Mean } \\
\text { Difference } \\
(I-J)\end{array}$} & \multirow{2}{*}{$\begin{array}{l}\text { Std. } \\
\text { Error }\end{array}$} & \multirow[t]{2}{*}{ Sig. } & \multicolumn{2}{|c|}{$95 \%$ Confidence Interval } \\
\hline & & & & & & Lower Bound & Upper Bound \\
\hline \multirow[t]{8}{*}{ InfoCom } & \multirow[t]{4}{*}{1} & 2 & $33437,500^{*}$ & 329,829 &, 000 & 31922,75 & 34952,25 \\
\hline & & 3 & $35559,750^{*}$ & 189,003 &, 000 & 34271,72 & 36847,78 \\
\hline & & 4 & $26004,500^{*}$ & 401,846 &, 000 & 23964,87 & 28044,13 \\
\hline & & 5 & $32974,500^{*}$ & 291,720 &, 000 & 31698,77 & 34250,23 \\
\hline & \multirow[t]{4}{*}{2} & 1 & $-33437,500^{*}$ & 329,829 &, 000 & $-34952,25$ & $-31922,75$ \\
\hline & & 3 & $2122,250^{*}$ & 275,027 &, 039 & 167,46 & 4077,04 \\
\hline & & 4 & $-7433,000^{*}$ & 448,775 & ,000 & $-9426,91$ & $-5439,09$ \\
\hline & & 5 & $-463,000$ & 353,580 & ,936 & $-2008,88$ & 1082,88 \\
\hline
\end{tabular}


Table 8 Tamhane's T2 comparisons for study locations including reference cities of Helsinki and Espoo (Continued)

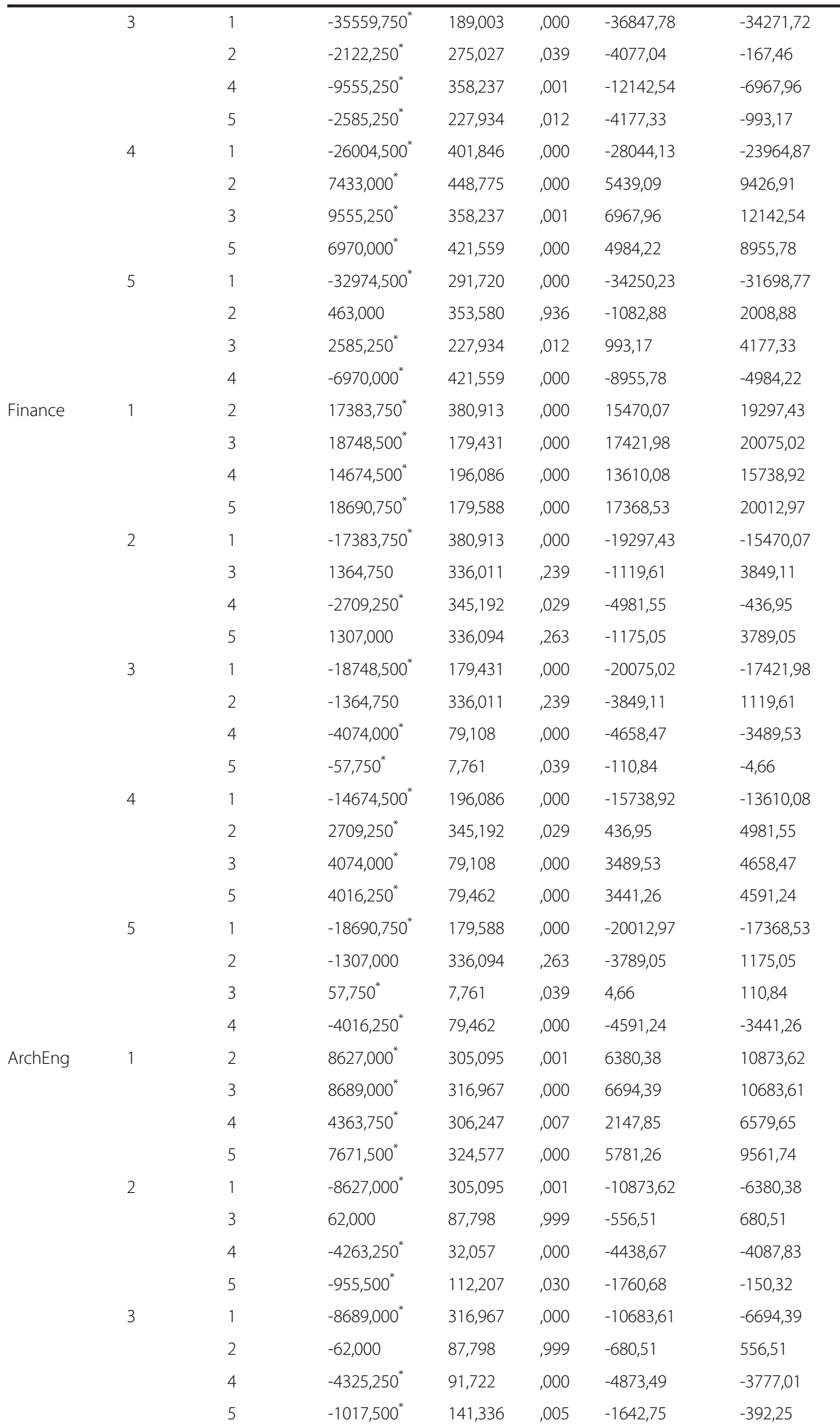


Table 8 Tamhane's T2 comparisons for study locations including reference cities of Helsinki and Espoo (Continued)

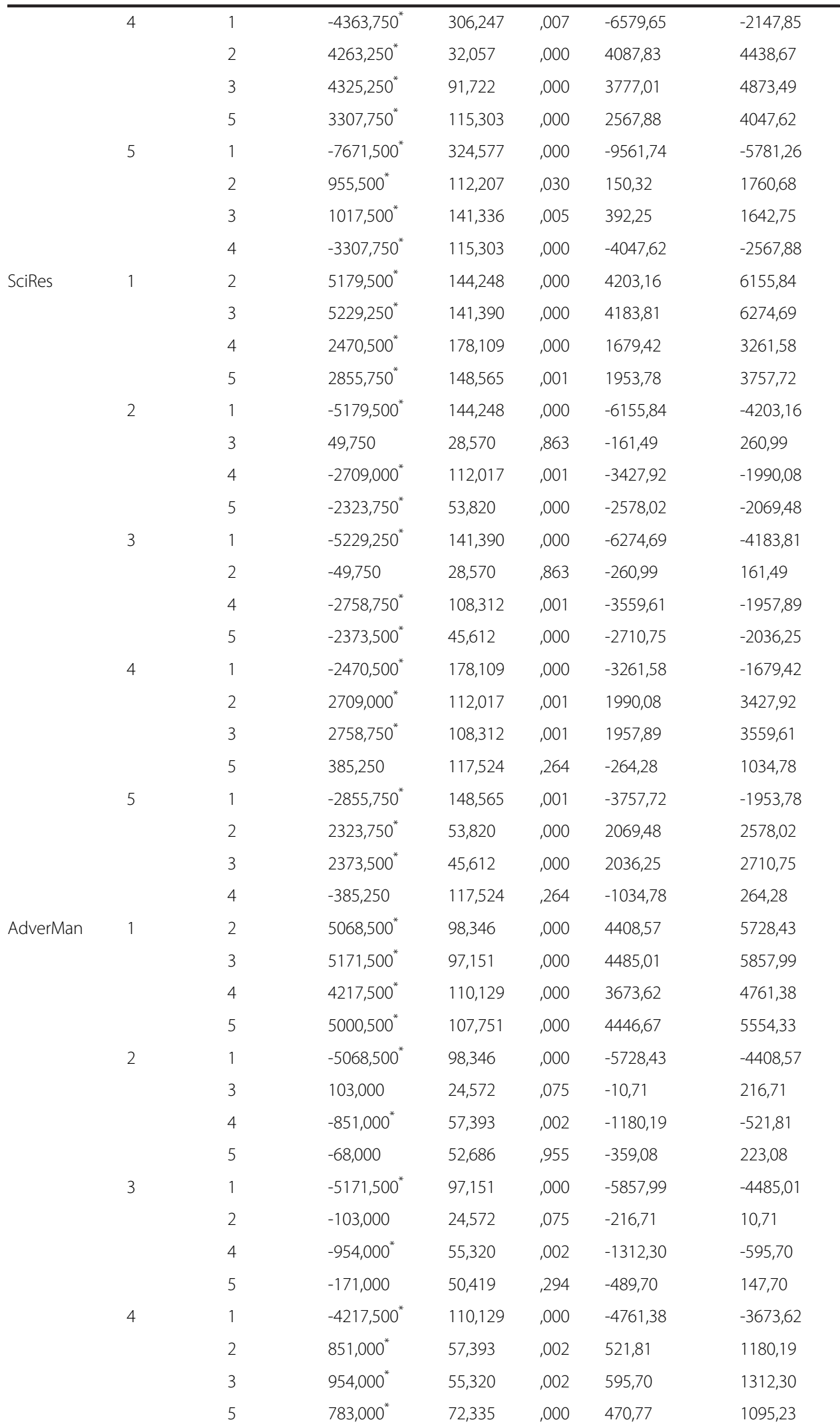


Table 8 Tamhane's T2 comparisons for study locations including reference cities of Helsinki and Espoo (Continued)

\begin{tabular}{|c|c|c|c|c|c|c|c|}
\hline & 5 & 1 & $-5000,500^{*}$ & 107,751 & ,000 & $-5554,33$ & $-4446,67$ \\
\hline & & 2 & 68,000 & 52,686 & ,955 & $-223,08$ & 359,08 \\
\hline & & 3 & 171,000 & 50,419 & ,294 & $-147,70$ & 489,70 \\
\hline & & 4 & $-783,000^{*}$ & 72,335 &, 000 & $-1095,23$ & $-470,77$ \\
\hline \multirow[t]{20}{*}{ SpecBus } & 1 & 2 & $3476,750^{*}$ & 74,164 &, 000 & 2933,82 & 4019,68 \\
\hline & & 3 & $3537,000^{*}$ & 74,036 &, 000 & 2990,58 & 4083,42 \\
\hline & & 4 & $2811,250^{*}$ & 75,443 &, 000 & 2298,94 & 3323,56 \\
\hline & & 5 & $3503,250^{*}$ & 74,728 &, 000 & 2974,72 & 4031,78 \\
\hline & 2 & 1 & $-3476,750^{*}$ & 74,164 &, 000 & $-4019,68$ & $-2933,82$ \\
\hline & & 3 & $60,250^{*}$ & 5,242 & ,003 & 31,45 & 89,05 \\
\hline & & 4 & $-665,500^{*}$ & 15,420 & ,000 & $-758,54$ & $-572,46$ \\
\hline & & 5 & 26,500 & 11,422 &, 553 & $-34,17$ & 87,17 \\
\hline & 3 & 1 & $-3537,000^{*}$ & 74,036 &, 000 & $-4083,42$ & $-2990,58$ \\
\hline & & 2 & $-60,250^{*}$ & 5,242 &, 003 & $-89,05$ & $-31,45$ \\
\hline & & 4 & $-725,750^{*}$ & 14,792 &, 000 & $-830,32$ & $-621,18$ \\
\hline & & 5 & $-33,750$ & 10,558 & ,366 & $-105,38$ & 37,88 \\
\hline & 4 & 1 & $-2811,250^{*}$ & 75,443 &, 000 & $-3323,56$ & $-2298,94$ \\
\hline & & 2 & $665,500^{*}$ & 15,420 &, 000 & 572,46 & 758,54 \\
\hline & & 3 & $725,750^{*}$ & 14,792 & ,000 & 621,18 & 830,32 \\
\hline & & 5 & $692,000^{*}$ & 17,939 &, 000 & 610,58 & 773,42 \\
\hline & 5 & 1 & $-3503,250^{*}$ & 74,728 &, 000 & $-4031,78$ & $-2974,72$ \\
\hline & & 2 & $-26,500$ & 11,422 &, 553 & $-87,17$ & 34,17 \\
\hline & & 3 & 33,750 & 10,558 & ,366 & $-37,88$ & 105,38 \\
\hline & & 4 & $-692,000^{*}$ & 17,939 &, 000 & $-773,42$ & $-610,58$ \\
\hline \multirow[t]{20}{*}{ TertEdu } & 1 & 2 & $9951,500^{*}$ & 305,625 & ,001 & 7692,68 & 12210,32 \\
\hline & & 3 & $9308,750^{*}$ & 306,494 & ,001 & 7073,51 & 11543,99 \\
\hline & & 4 & $5800,500^{*}$ & 343,896 &, 000 & 4048,84 & 7552,16 \\
\hline & & 5 & $6366,000^{*}$ & 342,748 &, 000 & 4608,75 & 8123,25 \\
\hline & 2 & 1 & $-9951,500^{*}$ & 305,625 & ,001 & $-12210,32$ & $-7692,68$ \\
\hline & & 3 & $-642,750^{*}$ & 23,794 & ,001 & $-806,99$ & $-478,51$ \\
\hline & & 4 & $-4151,000^{*}$ & 157,772 & ,001 & $-5315,68$ & $-2986,32$ \\
\hline & & 5 & $-3585,500^{*}$ & 155,254 & ,002 & $-4731,53$ & $-2439,47$ \\
\hline & 3 & 1 & $-9308,750^{*}$ & 306,494 & ,001 & $-11543,99$ & $-7073,51$ \\
\hline & & 2 & $642,750^{*}$ & 23,794 &, 001 & 478,51 & 806,99 \\
\hline & & 4 & $-3508,250^{*}$ & 159,450 &, 002 & $-4629,93$ & $-2386,57$ \\
\hline & & 5 & $-2942,750^{*}$ & 156,959 &, 003 & $-4045,20$ & $-1840,30$ \\
\hline & 4 & 1 & $-5800,500^{*}$ & 343,896 &, 000 & $-7552,16$ & $-4048,84$ \\
\hline & & 2 & $4151,000^{*}$ & 157,772 & ,001 & 2986,32 & 5315,68 \\
\hline & & 3 & $3508,250^{*}$ & 159,450 &, 002 & 2386,57 & 4629,93 \\
\hline & & 5 & 565,500 & 221,273 &, 357 & $-385,17$ & 1516,17 \\
\hline & 5 & 1 & $-6366,000^{*}$ & 342,748 & ,000 & $-8123,25$ & $-4608,75$ \\
\hline & & 2 & $3585,500^{*}$ & 155,254 & ,002 & 2439,47 & 4731,53 \\
\hline & & 3 & $2942,750^{*}$ & 156,959 &, 003 & 1840,30 & 4045,20 \\
\hline & & 4 & $-565,500$ & 221,273 &, 357 & $-1516,17$ & 385,17 \\
\hline
\end{tabular}


Table 8 Tamhane's T2 comparisons for study locations including reference cities of Helsinki and Espoo (Continued)

\begin{tabular}{|c|c|c|c|c|c|c|c|}
\hline \multirow[t]{20}{*}{ Arts } & \multirow[t]{4}{*}{1} & 2 & $9925,250^{*}$ & 97,878 &, 000 & 9241,84 & 10608,66 \\
\hline & & 3 & $10073,250^{*}$ & 96,728 &, 000 & 9360,79 & 10785,71 \\
\hline & & 4 & $7742,500^{*}$ & 151,500 &, 000 & 7080,55 & 8404,45 \\
\hline & & 5 & $10089,500^{*}$ & 96,867 &, 000 & 9380,82 & 10798,18 \\
\hline & \multirow[t]{4}{*}{2} & 1 & $-9925,250^{*}$ & 97,878 &, 000 & $-10608,66$ & $-9241,84$ \\
\hline & & 3 & $148,000^{*}$ & 15,947 &, 016 & 44,59 & 251,41 \\
\hline & & 4 & $-2182,750^{*}$ & 117,687 &, 003 & $-3018,77$ & $-1346,73$ \\
\hline & & 5 & $164,250^{*}$ & 16,770 &, 006 & 71,47 & 257,03 \\
\hline & \multirow[t]{4}{*}{3} & 1 & $-10073,250^{*}$ & 96,728 &, 000 & $-10785,71$ & $-9360,79$ \\
\hline & & 2 & $-148,000^{*}$ & 15,947 &, 016 & $-251,41$ & $-44,59$ \\
\hline & & 4 & $-2330,750^{*}$ & 116,732 & ,003 & $-3191,59$ & $-1469,91$ \\
\hline & & 5 & 16,250 & 7,576 &, 592 & $-20,09$ & 52,59 \\
\hline & \multirow[t]{4}{*}{4} & 1 & $-7742,500^{*}$ & 151,500 &, 000 & $-8404,45$ & $-7080,55$ \\
\hline & & 2 & $2182,750^{*}$ & 117,687 &, 003 & 1346,73 & 3018,77 \\
\hline & & 3 & $2330,750^{*}$ & 116,732 &, 003 & 1469,91 & 3191,59 \\
\hline & & 5 & $2347,000^{*}$ & 116,847 &, 003 & 1489,31 & 3204,69 \\
\hline & \multirow[t]{4}{*}{5} & 1 & $-10089,500^{*}$ & 96,867 &, 000 & $-10798,18$ & $-9380,82$ \\
\hline & & 2 & $-164,250^{*}$ & 16,770 &, 006 & $-257,03$ & $-71,47$ \\
\hline & & 3 & $-16,250$ & 7,576 &, 592 & $-52,59$ & 20,09 \\
\hline & & 4 & $-2347,000^{*}$ & 116,847 &, 003 & $-3204,69$ & $-1489,31$ \\
\hline
\end{tabular}

* The mean difference is significant at the 0.05 level

\section{Competing interests}

The author declares that he has no competing interests.

\section{Acknowledgement}

This work was presented as keynote speech of the SOItmC \& KCWS 2015 conference which was hosted by SOltmC and WCI during the period of June 14th-18th, 2015, at DGIST (www.dgist.ac.kr), Daegu, Korea. The inviting fee was paid from the research project under Dr. JoonWoo Son (DGIST), which is funded by the Ministry of Science, ICT and Future Planning of Korea. The publishing fee of this work was paid by the Open Innovation and Business Model Research Team of DGIST R\&D program, funded by the Ministry of Science, ICT and Future Planning of Korea. The research was funded by the Helsinki Metropolitan Region Urban Research Program.

Received: 9 April 2015 Accepted: 7 August 2015

Published online: 04 September 2015

\section{References}

Anttiroiko A. Science cities. Int J Technol Manag. 2004;28(3-6):395-418.

Asheim B, Gertler M. The geography of innovation: regional innovation systems. In: Fagerberg J, Mowery D, Nelson R, editors. The Oxford Handbook of Innovation. Oxford: Oxford University Press; 2005. p. 291-317.

Asheim B, Coenen L, Moodysson J, Vang J. Constructing knowledge-based regional advantage: Implications for regional innovation policy. Int J Entrep Innov Manag. 2007;7(2-5):140-55.

Asheim B, Boschma R, Cooke P. Constructing regional advantage: Platform policies based on related variety and differentiated knowledge bases. Reg Stud. 2011;45(7):893-904.

Capello R. Spatial transfer of knowledge in high-technology milieu: learning vs. collective learning processes. Reg Stud. 1999;33(4):353-65.

Chesbrough H. Open Innovation: The New Imperative for Creating And Profiting from Technology. Boston, MA: Harvard Business Review Press; 2003.

Chesbrough H, Vanhaverbeke W, West J. New Frontiers in Open Innovation. Oxford: Oxford University Press; 2014

Crevoisier O. The Innovative Milieus Approach: Toward a Territorialized Understanding of the Economy. Econ Geogr. 2004;80(4):367-79.

Crevoisier O. Beyond Territorial Innovation Models: The Pertinence of the Territorial Approach. Reg Stud. 2014:48 (3):551-61.

Etzkowitz $\mathrm{H}$, Klofsten $\mathrm{M}$. The innovative region: toward a theory of knowledge-based regional development. R\&D Manag. 2005;35(3):243-55. 
Fagerberg J, Verspagen B. Innovation Studies: The Emerging Structure of a New Scientific Field. Res Policy. 2009;38 (2):218-33.

Freeman C. Technology Policy and Economic Performance: Lessons from Japan. London: Pinter Publishers; 1987. Geels FW, Schot J. Typology of sociotechnical transition pathways. Res Policy. 2007;36(3):399-417.

Gertler M. Buzz without being there? Communities in of practice in context. In: Amin A, Roberts J, editors. Community, Economic Creativity and Organization. Oxford: Oxford University Press; 2008. p. 203-26.

Inkinen T. Urban travel information and wireless technologies in Helsinki, Finland. J Urban Tech. 2010;17(2):57-75.

Inkinen T, \& Kaakinen I. Economic Geography of Knowledge Intensive Technology Clusters: Lessons from the Helsinki Metropolitan Area. Accepted in Journal of Urban Technology, Routledge, ISSN; 1063-0732 (print), 2015;1466-1853 (online).

Inkinen T, Vaattovaara M. Technology and knowledge-based development. Helsinki metropolitan area as a creative region. ACRE report 2.5. Amsterdam: University of Amsterdam; 2007.

Inkinen T, Vaattovaara M. Creative urban region in the Nordic country. Combining tradition with development in Helsinki. In: Metaxiotis K, Carrillo FJ, Yigitcanlar T, editors. Knowledge-Based Development of Cities and Societies: Integrated Multi-Level Approaches. Hershey: IGI Global; 2010. p. 196-210.

Jokela S. Tourism, Geography and Nation-Building. The Identity-Political Role of Finnish Tourism Images. In: Department of Geosciences and Geography A 24. Helsinki: University of Helsinki; 2014.

Komninos N. Intelligent Cities. New York: Spon Press; 2002.

Lundvall B-Å. Product Innovation and User-Producer Interaction. Aalborg: Aalborg University Press; 1985.

Lundvall B-Å. National Innovation Systems: Towards a Theory of Innovation and Interactive Learning. London: Pinter Publishers; 1992.

Lundvall B-Å, Maskell P. Nation states and economic development - From national systems of production to national systems of knowledge creation and learning. In: Clark GL, Feldmann MP, Gertler MS, editors. The Oxford Handbook of Economic Geography. Oxford: Oxford University Press; 2000. p. 353-72.

Makkonen T, Inkinen T. Innovative capacity, workforce education and economic development in countries and regions of the European Union. Eur Plan Stud. 2013;21(12):1958-76.

Makkonen T, Inkinen T. Innovation quality in knowledge cities: Empirical evidence of innovation award competitions in Finland. Expert Syst Appl. 2014:41(12):5597-604.

Manniche J. Combinatorial knowledge dynamics: on the usefulness of the differentiated knowledge bases model. Eur Plan Stud. 2012;20(11):1823-41.

Martin R, Sunley P. Path dependence and regional economic evolution. J Econ Geogr. 2006;6(4):395-437.

Martin R, Sunley P. Complexity thinking and evolutionary economic geography. J Econ Geogr. 2007;7(5):573-601.

Musterd S, Bontje M, Chapain C, Kovács Z, Murie A. Accommodating Creative Knowledge. A Literature Review from a European Perspective. Acre report 1. Amsterdam: University of Amsterdam; 2007.

Nelson RR, editor. National Innovation Systems: A Comparative Analysis. Oxford: Oxford University Press; 1993.

Nonaka I, Takeuchi H. The Knowledge Creating Company. Oxford: Oxford University Press; 1995.

Rutten R, Boekema F. Beyond the Learning Region: A New Direction for Conceptualizing the Relation between Space and Learning. Eur Plan Stud. 2013;21(5):722-34.

Simmie J. Innovative Cities. New York: Spon Press; 2001.

Simmie J. Innovation and Space: a critical review of the literature. Reg Stud. 2005;39(6):789-804.

Yigitcanlar T, Lönnqvist A. Benchmarking knowledge-based urban development performance: results from the international comparison of Helsinki. Cities. 2013;31(1):357-69.

Yigitcanlar T, Inkinen T, \& Makkonen T. Does Size Matter? Knowledge-Based Development of Second-Order City-Regions in Finland. disP - The Planning Review 2015;51(3):56-71.

\section{Submit your manuscript to a SpringerOpen ${ }^{\circ}$ journal and benefit from:}

- Convenient online submission

- Rigorous peer review

- Immediate publication on acceptance

- Open access: articles freely available online

- High visibility within the field

- Retaining the copyright to your article

Submit your next manuscript at $>$ springeropen.com 